\title{
Vegetable Grafting for Enhancing Yield and Combating Biotic Stress in Bhut Jolokia (Capsicum chinense) under Protected Condition
}

\author{
Rinku Moni Phukon*, Sarat Saikia, P. Borah, Sibani Das, \\ Seema Bhagowati and Ranjita Bezbaruah
}

\author{
Horticultural Research Station, Assam Agricultural University, Kahikuchi, \\ Guwahati, Assam, India \\ *Corresponding author
}

\section{A B S T R A C T}

\begin{tabular}{|l|}
\hline Ke y w o r d s \\
Grafting, King \\
chilli, Protected \\
condition, Mem \\
Jolokia, Moni \\
Jolokia
\end{tabular}

Grafting of vegetable seedlings is a unique horticultural technology practiced to improve plant production, reduce disease susceptibility and increase plant vigour. This technology was introduced to Europe and other countries in the late 20th century along with improved grafting methods suitable for commercial production of grafted vegetable seedlings. Grafting onto specific rootstocks generally provides resistance to soil borne diseases and nematodes and increases yield. With the aim of determining whether grafting could improve to manage soil-borne diseases of king chilli (Capsicum chinense), a polyhouse experiment was carried out to determine growth, yield and fruit quality of king chilli grafted on two locally available disease free rootstocks viz., Mem Jolokia (Capsicum frutescens) and Moni Jolokia (Capsicum frutescens).

\section{Introduction}

The northeast region of India, is considered as "hot spot'" of biodiversity, having hot and high-humidity conditions with unique ecological environment, has given rise to the world's hottest chilly (king Chilli), "Bhut jolokia" or "Bih jolokia"e, which is at least two times hotter in terms of Scoville heat units (SHU). The Assamese word "bhut" refers to the typical large pod size of the plant, while the term "bih" means "poison" indicating the high hotness in the fruits of the plant. It is extensively grown in North Eastern region of India, predominantly in the states of Assam, Nagaland, Manipur and Mizoram since ancient time. The main pungency principle of Bhut jolokia is capsaicin (8-methyl-Nvanillyl-6-nonenamide) and its analogs collectively known as capsaicinoids synthesized in the epidermal cells of placenta of the fruit, and possesses anti-inflammatory and antioxidant activities. Bhut jolokia is a self-pollinated plant, however, considerable cross pollination (up to 10\%) may occur when insect population is high. It behaves as a 
semi-perennial herb if grown under optimal condition.

Grafting is now a days becoming an important tool to manage soil-borne disease and improve crop to different stresses such as drought, flooding, salinity and extreme temperature stresses. However, in order to make a successful change in plant root system through grafting, it is important to select an ideal and compatible rootstock. In present study two locally available disease free root stock viz., Mem Jolokia and Moni Jolokia were taken.

The experiment was carried out with the following objectives:

To assess the comparative performance of different indigenous solonaceous species as rootstock for Grafting

To study the rootstock-scion compatibility involving indigenous solonaceous species as rootstock in King Chilli as scion

To evaluate the growth and yield of grafted King Chilli under protected condition

To study the incidence of bacterial wilt in Grafted plant

\section{Materials and Methods}

In the present studies, the indigenous chilli varieties viz., Mem Jolokia and Moni Jolokia were taken as a rootstock for grafting on king chilli. Wedge grafting was done in the experiment. Seeds of two different rootstocks of chilli were sown 15 days before the sowing of the scion during September, that was to ensure similar stem diameters at the time of grafting. Seeds were sown in a coco peat and vermicompost substrate in 96 holes trays inside a polyhouse in Horticultural Research Station, Kahikuchi, Assam Agricultural University. Grafting was done after 60 days of sowing of seeds of the rootstock and 45 days of sowing of seeds of the scion. The grafted plants were kept under a transparent plastic cover at $28^{\circ} \mathrm{C}$ and around $90 \%$ relative humidity. The grafted seedlings were established almost one month after grafting. Then the seedlings were transplanted into the main field (Protected house) with a spacing between plants was $50 \mathrm{~cm}$ and that between rows was $60 \mathrm{~cm}$. Regular cultural practices such as irrigation, weeding, fertilizer and pesticide application were followed. The productivity of the grafted chilli plants as measured by compatibility, height, the number of branches, fruit yield, fruit length, fruit width at shoulder, individual fruit weight and seeds per fruits at 1,2,3,4,5,6 months of post grafting was recorded. Fruits of Chilli were picked and weighed at intervals throughout the growing season and total yield ( $\mathrm{g}$ plant ${ }^{-1}$ ) was determined at the end of experiment.

Data analysis: Statistical analysis was performed using 'SPSS 11.0 Windows' and the differences between the means were compared using the criterion of the Duncan's multiple range test and $\operatorname{LSD}(\mathrm{P}=0.05)$

\section{Results and Discussion}

The success percentage of grafting King chilli scion on Mem and Moni Jolokia rootstocks in this investigation was $80 \%$ and $75 \%$ respectively (Table 1). Days taken for graft union for both the rootstocks were at per i.e. 7-8days. Plant height was significantly affected by grafting than the control one. The two chilli grafts had variable heights during the cropping period after grafting (Table 2). This result agrees with the results of Lee (1994) and Ioannou et al., (2002) who found that grafted plants were taller and more vigorous than self-rooted ones and had a larger central stem diameter. The two grafts were not much differences in order to primary and secondary branch per plant. It is obvious 
that no. of fruits per plant was increased after four months of grafting. Significant differences were found in no. of fruits per plant. There were significant difference among treatments as of fresh weight of yield of all chilli grafts compared with both the rootstocks and control as shown in Table 2. The incidence of bacterial wilt which is the major impediment in growing king chilli was recorded only $6.6 \%$ in Mem Jolokia as compared to Moni Jolokia (Table 1; Fig.1 and 2).

Table.1 Success of Bhut jolokia grafting on Mem jolokia and Moni jolokia rootstock

\begin{tabular}{|l|c|c|c|c|c|}
\hline Root stock & $\begin{array}{c}\text { No. of } \\
\text { grafting }\end{array}$ & $\begin{array}{c}\text { No. of success } \\
\text { graft union }\end{array}$ & Success (\%) & $\begin{array}{c}\text { Days taken for } \\
\text { graft union }\end{array}$ & $\begin{array}{c}\text { Bacterial wilt } \\
\text { incidence (\%) }\end{array}$ \\
\hline Mem jolokia & $60^{\mathrm{a}}$ & $48^{\mathrm{b}}$ & $80^{\mathrm{c}}$ & $7-8^{\mathrm{d}}$ & $6.66^{\mathrm{a}}$ \\
\hline Moni Jolokia & $60^{\mathrm{a}}$ & $45^{\mathrm{b}}$ & $75^{\mathrm{c}}$ & $7-8^{\mathrm{d}}$ & $13.33^{\mathrm{b}}$ \\
\hline Mean & $60^{\mathrm{a}}$ & $46.5^{\mathrm{b}}$ & $77.5^{\mathrm{c}}$ & $7-8^{\mathrm{d}}$ & $9.99^{\mathrm{ab}}$ \\
\hline
\end{tabular}

Means within columns separated using Duncan's multiple range test, $p=0.05$

Table.2 Growth and yield attributing characters and total of MeB (Mem jolokia + Bhutjolokia), $\mathrm{MiB}$ (Moni jolokia + Bhut jolokia) graft combination and $\mathrm{B}$ (non grafted)

\begin{tabular}{|c|c|c|c|c|c|c|c|c|c|c|c|c|c|c|c|}
\hline \multirow[t]{2}{*}{$\begin{array}{l}\text { Date of } \\
\text { observation }\end{array}$} & \multicolumn{3}{|c|}{ Plant height (cm) } & \multicolumn{3}{|c|}{$\begin{array}{l}\text { No. of primary } \\
\text { branches/plant }\end{array}$} & \multicolumn{3}{|c|}{$\begin{array}{l}\text { No. of Secondary } \\
\text { branches/plant }\end{array}$} & \multicolumn{3}{|c|}{ No. of fruits/plant } & \multicolumn{3}{|c|}{ Yield /plant (g) } \\
\hline & MeB & MiB & B & MeB & MiB & B & МeB & MiB & B & MeB & MiB & B & MeB & MiB & B \\
\hline At planting & 41.93 & 36.25 & 30.8 & 3.66 & 3.33 & 3.2 & 3.00 & 2.40 & 2.4 & Nil & Nil & Nil & Nil & Nil & Nil \\
\hline $\begin{array}{l}\text { One month } \\
\text { after } \\
\text { planting }\end{array}$ & 59.00 & 45.00 & 40.1 & 4.33 & 4.00 & 4.0 & 6.66 & 6.33 & 6.2 & Nil & Nil & Nil & Nil & Nil & Nil \\
\hline $\begin{array}{l}\text { Two month } \\
\text { after } \\
\text { planting }\end{array}$ & 74.33 & 67.00. & 55.0 & 6.00 & 5.20 & 5.1 & 10.00 & 9.20 & 9.1 & 13 & 8 & 5 & 75.00 & 65.00 & 40.5 \\
\hline $\begin{array}{l}\text { Three } \\
\text { month } \\
\text { after } \\
\text { planting }\end{array}$ & 102.33 & 94.33 & 72.5 & 6.33 & 5.66 & 5.56 & 12.00 & 11.40 & 11.5 & 23 & 18 & 15 & 130.00 & 90.00 & 87.5 \\
\hline $\begin{array}{l}\text { Four } \\
\text { month } \\
\text { after } \\
\text { planting }\end{array}$ & 123.33 & 102.33 & 92.6 & 7.00 & 6.40 & 6.4 & 13.67 & 12.33 & 12.4 & 52 & 41 & 36 & 275.00 & 220.00 & 200.0 \\
\hline $\begin{array}{l}\text { Five } \\
\text { month } \\
\text { after } \\
\text { planting }\end{array}$ & 138.00 & 123.00 & 110 & 7.80 & 7.20 & 7.15 & 14,20 & 13.00 & 13.0 & 70 & 56 & 50 & 395.00 & 292.00 & 268.0 \\
\hline $\begin{array}{l}\text { Sixth } \\
\text { month } \\
\text { after } \\
\text { planting }\end{array}$ & 141.60 & 132.20 & 125 & 8.00 & 7.80 & 7.9 & 14.20 & 13.33 & 13.2 & 35 & 30 & 30 & 190.00 & 172.00 & 170.0 \\
\hline Total & $680.52^{\mathrm{a}}$ & $533.11^{b}$ & $495.2^{c}$ & $43.12^{\mathrm{a}}$ & $39.59^{b}$ & $39.31^{b}$ & $59.53^{a}$ & $67.99^{b}$ & $67.8^{\mathrm{b}}$ & $193^{a}$ & $153^{b}$ & $136^{\mathrm{c}}$ & $1065^{a}$ & $839^{\mathrm{b}}$ & $766^{c}$ \\
\hline
\end{tabular}

Means followed by the same letter are statistically not significant (Duncan's multiple range test, $\mathrm{P}=0.05$ ) 
Table.3 Fruit characters of MeB (Mem jolokia + Bhutjolokia), MiB (Moni jolokia + Bhut jolokia) graft combination and B (non grafted)

\begin{tabular}{|l|l|l|l|}
\hline Observations & MeB & MiB & B \\
\hline Fruit length $(\mathbf{c m})$ & $6.50^{\mathrm{a}}$ & $6.78^{\mathrm{a}}$ & $6.35^{\mathrm{a}}$ \\
\hline Fruit width at shoulder $\mathbf{( c m )}$ & $2.85^{\mathrm{a}}$ & $2.64^{\mathrm{a}}$ & $2.54^{\mathrm{a}}$ \\
\hline Individual fruit weight $\mathbf{( g )}$ & $5.18^{\mathrm{a}}$ & $5.10^{\mathrm{a}}$ & $5.00^{\mathrm{a}}$ \\
\hline Seeds per fruits & $25^{\mathrm{a}}$ & $24^{\mathrm{a}}$ & $21^{\mathrm{a}}$ \\
\hline
\end{tabular}

Means followed by the same letter are statistically not significant (Duncan's multiple range test, $\mathrm{P}=0.05)$

Fig.1

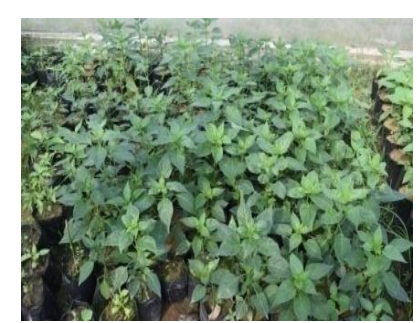

Capsicum frutescens (Mem jolokia)

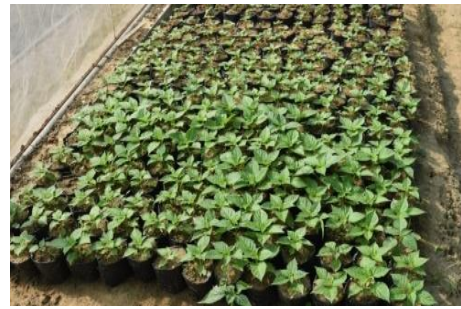

Capsicum frutescens (Moni jalokia)

Fig.2 Steps of grafting
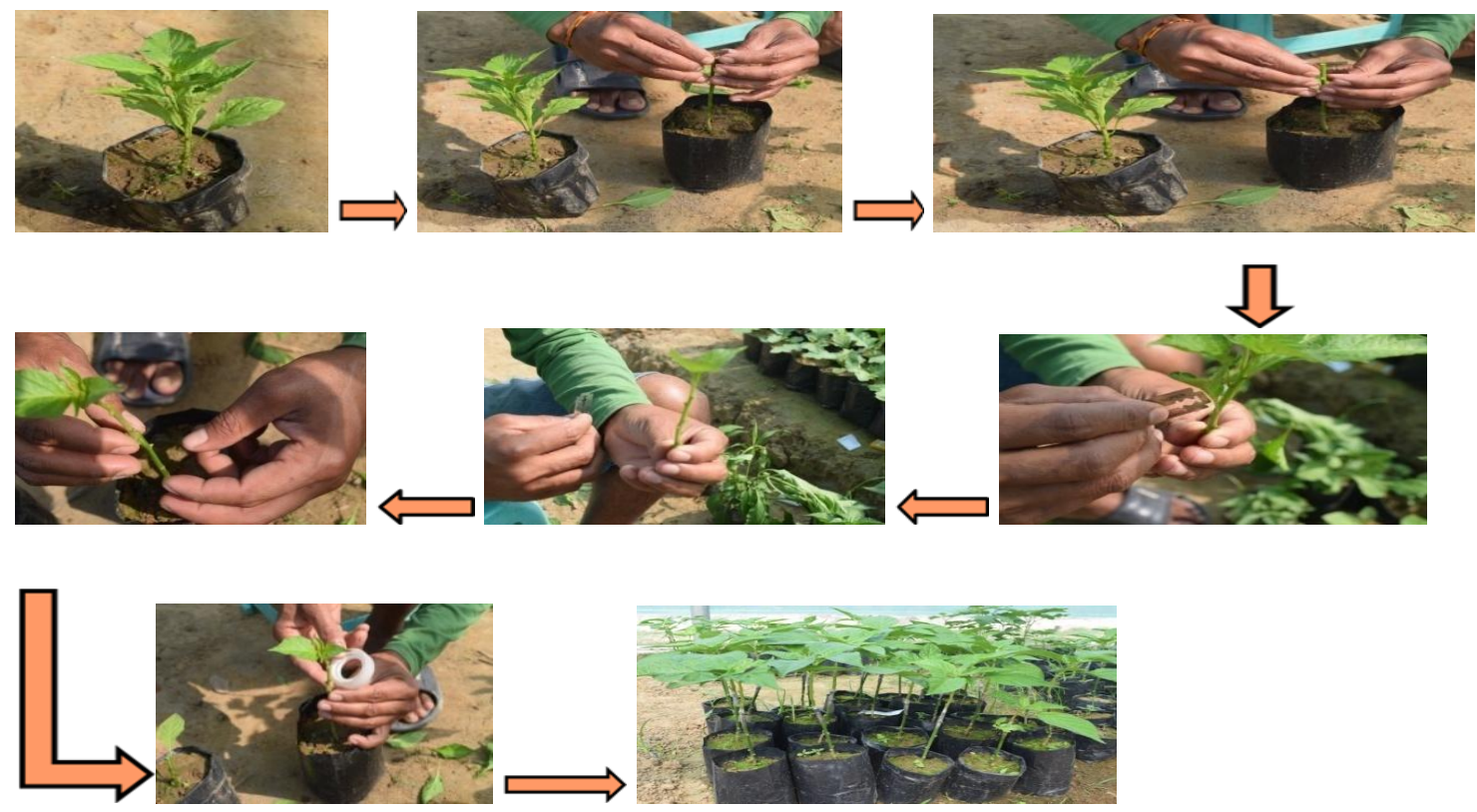
Regarding fruit characters (Table 3) there were no significant difference between 3 treatments in fruit length, fruit width at shoulder, individual fruit weight and seeds per fruit. However fruit characters in both the graft combinations slightly higher than control.

In conclusion from the growth and yield parameters assessed during the study Feb-Mar and Sep-Oct is the ideal time for grafting of King chilli. The chilli rootstock Mem Jolokia was found most suitable rootstock which was much more compatible compared to Moni Jolokia. These varieties can be used for commercial cultivation to combat bacterial wilt. However further trial is required in open condition.

\section{References}

Bersi, M. 2002. Tomato Grafting as an Alternative to Methyl Bromide in Marocco. Institut Agronomieque et Veterinaire Hasan II. Marocco.

Buller S, Inglis D, Miles C. 2013. Horticultural Sciences.; 48(8): 10031009.

Colla, G. et al. 2008. Influence of Grafting on Yield and Fruit Quality of Pepper (Capsicum annum L.) Grown under Greenhouse Conditions. Acta Horticulturae, February.

Edelstein, M.2004. Grafting Vegetable Crops Plants: Pros and Cons. Acta Hort. (ISHS) 659: 235-238.

Kubota, C. 2007. Vegetable Grafting: History, Use and Current Technology Status in
North America. HortScience 42:801 (abstr.).

Lee, J.M. and Oda, M. 2003. Grafting of Herbaceous Vegetables and Ornamental Crops. Horticultural Reviews 28:61124.

Lee, J.M. 1994. Cultivation of grafted vegetables I, current status, grafting methods and benefits. Hort Science, 29: 235-239.

Leonardi, C. and D. Romano, 2004. Recent issues on vegetable grafting. Acta Horticulturae, 631: 163-174.

Morra, L. and Bilotto, M. 2006. Evaluation of new rootstocks for resistance to soil borne pathogens and productive behaviour of pepper (Capsicum annum L.) Jr. of Horticultural Science and Biotech.81:518-524.

Pardeep, K, Shivani R, Parveen S, Viplove N. Vegetable Grafting .2015: A boon to vegetable growers to combat biotic and abiotic stresses. Himachal Journal of Agricultural Research. 41(1): 1-5.

Rakesh Kumar V, Rajashree, Lalichetti Sagar, Amit Ahuja N, Savithiri K, Karthick, Amritpal Mehta, Rajech Saini.2018. Vegetable grafting: A recent advance in olericulture: A review. Int.J.Curr.Microbiol.App.Sci 7(09): 1877-1882.

Tirupathamma Lakshmi T, Venkata Ramana C, Naram Naidu L. and Sasikala K. 2019. Vegetable Grafting: A Multiple Crop Improvement Methodology Current Journal of Applied Science and Technology. 33(3): 1-10.

\section{How to cite this article:}

Rinku Moni Phukon, Sarat Saikia, P. Borah, Sibani Das, Seema Bhagowati and Ranjita Bezbaruah. 2020. Vegetable Grafting for Enhancing Yield and Combating Biotic Stress in Bhut Jolokia (Capsicum chinense) under Protected Condition. Int.J.Curr.Microbiol.App.Sci. 9(09): 3051-3055. doi: https://doi.org/10.20546/ijcmas.2020.909.376 